\title{
'Speaking Kleinian': Susan Isaacs as Ursula Wise and the Inter-War Popularisation of Psychoanalysis
}

\author{
MICHAL SHAPIRA * \\ Tel Aviv University, Gilman Building, Room 374, Tel Aviv, 69978, Israel
}

\begin{abstract}
How did the complex concepts of psychoanalysis become popular in early twentieth-century Britain? This article examines the contribution of educator and psychoanalyst Susan Isaacs (1885-1948) to this process, as well as her role as a female expert in the intellectual and medical history of this period. Isaacs was one of the most influential British psychologists of the inter-war era, yet historical research on her work is still limited. The article focuses on her writing as 'Ursula Wise', answering the questions of parents and nursery nurses in the popular journal Nursery World, from 1929 to 1936 . Researched in depth for the first time, Isaacs' important magazine columns reveal that her writing was instrumental in disseminating the work of psychoanalyst Melanie Klein in Britain. Moreover, Isaacs' powerful rebuttals to behaviourist, disciplinarian parenting methods helped shift the focus of caregivers to the child's perspective, encouraging them to acknowledge children as independent subjects and future democratic citizens. Like other early psychoanalysts, Isaacs was not an elitist; she was in fact committed to disseminating her ideas as broadly as possible. Isaacs taught British parents and child caregivers to 'speak Kleinian', translating Klein's intellectual ideas into ordinary language and thus enabling their swift integration into popular discourse.
\end{abstract}

Keywords: History of psychoanalysis, Susan Isaacs, Melanie Klein, Child psychology, Inter-war Britain

Contrary to the common assumption that psychoanalysis was not popular in Britain, revisionist historians have recently revealed that it was discussed in various forums throughout the first half of the twentieth century. ${ }^{1}$ Between the wars, 'psycho-analysis

* Email address for correspondence: michal1s@ post.tau.ac.il

${ }^{1}$ See Michal Shapira, The War Inside: Psychoanalysis, Total War and the Making of the Democratic Citizen in Postwar Britain (Cambridge: Cambridge University Press, 2013); Sandra Ellesley, Psychoanalysis in Early Twentieth Century England: A Study in the Popularization of Ideas (unpublished PhD thesis: University of Essex, 1995); Dean Rapp, 'The Reception of Freud by the British Press: General Interest and Literary Magazines, 19205', Journal of the History of the Behavioral Sciences, 24 (1988), 191-201; Dean Rapp, 'The Early Discovery of Freud by the British General Educated Public, 1912-19', Social History of Medicine, 3, 2 (1990), 217-43; Graham Richards, 'Britain on the Couch: The Popularization of Psychoanalysis in Britain, 1918-40', Science in Context 13 (2000), 183-230; John Forrester, 'Freud in Cambridge', Critical Quarterly, 46, 2 (2004), 1-26; Sally Alexander, 'Primary maternal preoccupation: D.W. Winnicott and social democracy in mid-twentieth century Britain', in Sally Alexander and Barnard Taylor (eds), History and Psyche: Culture, Psychoanalysis and the Past (London: Palgrave, 2012), 149-68; Daniel Pick, Pursuit of the Nazi Mind: Hitler, Hess and the Analysts (Oxford: Oxford University Press, 2012). 
became a craze as well as a serious study'. ${ }^{2}$ It was widely debated, often in positive terms, among the general educated public in a wave of popular science books, magazine articles and novels. ${ }^{3}$ Psychoanalytic ideas about the child, in particular, spread far beyond the British Psychoanalytical Society (BPAS). This development did not occur without resistance; nevertheless, by the middle of the century, psychoanalytic ideas and terminology had become ingrained in Britain's social and cultural imagination. ${ }^{4}$

How did the complex concepts of psychoanalysis become so popular in Britain? The educator and psychoanalyst Susan Isaacs made an important contribution to this process, and this article explores in depth her famed role as 'Ursula Wise', who answered the questions raised by parents and nursery nurses in the popular journal Nursery World from 1929 to 1936. These important magazine columns were found at the Isaacs Archive at the Institute of Education, University of London, and are explored here in depth for the first time. ${ }^{5}$ They reveal the ways in which Isaacs was instrumental in disseminating the work of the psychoanalyst Melanie Klein in Britain. Moreover, in Isaacs' powerful rebuttals to behaviourist, disciplinarian, parenting methods, she shifted the focus of caregivers to the perspective of the child, encouraging them to acknowledge children as independent subjects living in a democratic environment.

Though Susan Isaacs (1885-1948) was one of the most influential British psychologists of the inter-war era, research by professional historians into her work and her significant role in popularising psychoanalysis in this period is still limited. ${ }^{6}$ Isaacs embraced a remarkably wide range of professional activities, institutional affiliations and intellectual preoccupations - all centring on the modern interest of scientifically 'studying the child'. ${ }^{7}$ Her widely-circulated writings in magazines, journals and books, and her radio broadcasts on childcare, interested professionals as well as the educated lay public,

${ }^{2}$ Charles Mowat, Britain between the Wars 1918-40 (London: University of Chicago Press, 1955), 214; Robert Graves and Alan Hodge, The Long Weekend: A Social History of Great Britain 1918-39 (London: Faber \& Faber, 1940), 103. See also R. D. Hinshelwood, 'Psychoanalysis in Britain: Points of Cultural Access, 18931918', International Journal of Psychoanalysis, 76 (1995), 135-51.

${ }^{3}$ See Richards, op. cit. (note 1).

${ }^{4}$ Shapira, op. cit. (note 1). On the eclectic nature of psychology at the time and for theories beyond psychoanalysis, see Mathew Thomson, Psychological Subjects: Identity, Culture, and Health in TwentiethCentury Britain (Oxford: Oxford University Press, 2006); Rhodri Hayward, The Transformation of the Psyche in British Primary Care, 1880-1970 (London: Bloomsbury, 2014).

${ }^{5}$ See press cuttings at the DC/SI Papers of Susan Isaacs Collection at the Archives of the Institute of Education, London. All the unpublished magazine columns I used and referenced below are taken from the Archives.

${ }^{6}$ See Adrian Woolridge, Measuring the Mind: Education and Psychology in England c. 1860-1990 (Cambridge: Cambridge University Press, 1994), 111-35; Laura Cameron, 'Science, Nature and Hatred: "Finding Out" at the Malting House Garden School, 1924-9', Environment and Planning D: Society and Space 24 (2006), 851-72. For more information on her life, see these biographies (not written by historians): Dorothy E. M. Gardner, Susan Isaacs (London: Methuen, 1969); Philip Graham, Susan Isaacs: A Life Freeing the Minds of Children (London: Karnac, 2009); Lydia A. H. Smith (ed.), To Understand and to Help: The Life and Work of Susan Isaacs (18851948) (London: Associated University Press, 1985). Shaul Bar-Haim finds the existing literature on Isaacs to be relatively wide, but he also agrees that many aspects of her life and work are still overlooked. See Shaul BarHaim, 'The Liberal Playground: Susan Isaacs, Psychoanalysis and Progressive Education in the Interwar Era', History of the Human Sciences, 30 (2017), 95.

${ }^{7}$ On the emerging scientific interest in childhood see: Denise Riley, War in the Nursery: Theories of the Child and Mother (London: Virago, 1983); Nikolas Rose, The Psychological Complex: Psychology, Politics and Society in England, 1869-1939 (London: K. Paul, 1985); Christina Hardyment, Dream Babies: Child Care from Locke to Spock (London: Cape, 1983); Daniel Beekman, The Mechanical Baby: A Popular History of the Theory and Practice of Child Raising (London: Dobson, 1977); Deborah Dwork, War is Good for Babies and Other Young Children: A History of the Infant and Child Welfare Movement in England, 1898-1918 (New York: Tavistock Publications, 1987); Lutz D. H. Sauerteig, 'Loss of Innocence: Albert Moll, Sigmund Freud and the Invention of Childhood Sexuality around 1900', Medical History, 56 (2012), 156-83. 
thanks to her gift for weaving together the emerging disciplines of education, psychology and psychoanalysis. ${ }^{8}$ Isaacs first became known for publishing two books describing her observation of children at the Malting House School in Cambridge, a progressive institution based on 'discovery though play', where she worked between 1924 and $1927 .{ }^{9}$ The Nursery Years (1929) and The Children We Teach (1932) became important books for parents, nurses and teachers. In these, she argued that understanding children's minds and emotions can replace punitive discipline, strict consistency and stern parenting. ${ }^{10}$ In 1933, Isaacs was appointed head of the newly formed Department of Child Development at the University of London. Her pioneering work there allowed her to influence children's education, lifting the field's earlier resistance to theories of developmental psychology and psychoanalysis. Through her teaching, she became the most influential figure in education theory and practice in twentieth-century Britain. ${ }^{11}$ Among those of her generation, Isaacs was the most successful in introducing psychoanalysis to educational psychologists and the general public. ${ }^{12}$

Indeed, Isaacs was a female pioneer psychoanalyst, one of the first in Britain, and an early follower of child psychoanalyst Melanie Klein. Hailing from an academic background in education, philosophy, logic and psychology, Isaacs was analysed by J.C. Flugel. She became an associate member of the BPAS in 1921 (only two years after its founding in 1919), and a full member in 1923. When Klein, who was living in Berlin, first visited Britain in 1925, Isaacs met her and soon became a supporter of her ideas. Klein relocated to Britain permanently in 1926, and Isaacs underwent further analysis with the Kleinian Joan Riviere. ${ }^{13}$

Throughout her career, Isaacs remained committed to writing in popular formats. She addressed educated parents in the magazines Parents' Review, Mind, Mother and Child, Home and School and New Era. Her influence as an educator and Kleinian psychoanalyst was particularly effective through her 'Ursula Wise' columns in Nursery World. Like psychoanalysts Donald Winnicott and John Bowlby - whose work is better known today Isaacs was a great inter-war populariser of psychoanalysis. Because women were viewed as natural caregivers, it was easier for Isaacs and women of her generation to carve out a place for themselves as female experts. Their work positioned women psychologists as equal to male medical experts. ${ }^{14}$

\footnotetext{
${ }^{8}$ Woolridge, op. cit. (note 6), 111-35.

${ }^{9}$ Susan Isaacs, Intellectual Growth in Young Children (London: Routledge, 1930); Susan Isaacs, Social Development in Young Children (London: Routledge, 1933).

${ }^{10}$ Susan Isaacs, The Nursery Years: Birth to Six (London: Routledge, 1929); Susan Isaacs, The Children We Teach: Seven to Eleven Years (London: University of London Press, 1932); Malcolm Pines, 'Isaacs, Susan Sutherland (1885-1948)', (2004), Oxford Dictionary of National Biography Online.

11 As suggested by Pines, op. cit. (note 10).

12 As suggested in Woolridge, op. cit. (note 6), 111. For a summary of her career see Gardner, op. cit. (note 6) Appendix III, 185-6; John Rickman, 'Susan Sutherland Isaacs, C.B.E., M.A., D.Sc. (Vict.), Hon. D.Sc. (Adelaide)', International Journal of Psycho-Analysis, 31 (1950), 279-85.

13 Woolridge, op. cit. (note 6), 114. Traces of Klein's early 1920s papers could be found in Isaacs' magazine writings. The most marked influence comes from the following essays: Melanie Klein, 'The development of a child' [1921] and 'The role of the school in the libidinal development of the child' [1923] in Melanie Klein, Love, Guilt and Reparation: And Other Works 1921-45 (New York: Free Press, 2002), 1-54, 59-76. As is well known, later on, it was actually Isaacs who in the 1940s contributed the most important paper to the Kleinian canon: Susan Isaacs, 'The nature and function of phantasy', in Pearl King and Riccardo Steiner (eds), The Freud-Klein Controversies, 1941-5 (New York: Routledge, 1991), 264-321.

${ }^{14}$ Male analysts like Sándor Ferenczi and Karl Abraham encouraged Klein, for example, to analyse children, something that they and other male physicians saw as particularly suitable for women. See Melanie Klein,
} 
Indeed, as other innovative historical accounts demonstrate, early psychoanalysts were not elitists confined to the private clinic. Instead, experts reached beyond the couch and were committed to broadly disseminating their ideas. ${ }^{15}$ In her Ursula Wise columns, Isaacs taught British parents and child caregivers to 'speak Kleinian', translating Klein's intellectual ideas into ordinary language and thus enabling its swift integration into popular discourse. ${ }^{16}$ Did Isaacs' simplification obscure Klein's more radical ideas? Were readers open to these new theories and, if not, how did they challenge them? How did the magazine column format shape Isaacs' relationship with her readers?? Looking at her columns, we shall see how she positioned analytic ideas as an argument against widespread behaviourist approaches. Isaacs called for an understanding of child psychology and emotions instead of emphasising regularity above all else. Moreover, Isaacs passed her expert authority on to her readers, instilling in them an interest in exploring the 'inner lives' of children and, as a result, creating a new popular conception of children as individual subjects living in a democracy.

\section{Background}

In order to understand the significance of Isaacs' work, it is necessary to examine the background to her education and training and her intellectual environment, particularly with reference to medical history. Isaacs did more than anyone of her generation to introduce the diverse theories of Jean Piaget, Sigmund Freud and Melanie Klein into Britain. Her intellectual origins were diverse. Yet by the time she wrote the Ursula Wise columns, her commitment to Klein had become dominant. It was through her writing that she played a leading role in popularising Klein's ideas against competing theories. ${ }^{17}$

Isaacs was born in Lancashire to William Fairhurst, a journalist and Methodist lay preacher, and Miriam Sutherland, a homemaker. Her early family life was difficult: her brother and mother died at a young age and her father married the nurse that had attended her mother. Isaacs became a rebellious, agnostic youth, a member of the Fabian Society and a supporter of women's suffrage. In 1900, she trained as a teacher at Manchester University, eventually earning a degree in philosophy. This was followed by a scholarship to Cambridge, an early hub of psychology and psychoanalysis, which led to her lifelong interest in these emerging disciplines. ${ }^{18}$ From 1913 to 1915 , she taught school teachers at Darlington Training College, and subsequently logic at Manchester University. She married William Broadhurst Brierley, a botany lecturer, and moved to London to teach psychology. In 1922, she divorced and married Nathan Isaacs, a metal merchant with ties to Bloomsbury's intellectual bohemians and a broad interest in psychology and education. ${ }^{19}$

\footnotetext{
Autobiography - Dictated Incomplete Autobiography of K, Melanie Klein's Collection at the Contemporary Medical Archives Centre of the Wellcome Institute, CMAC/PP/KLE/A.52.

15 See note 1 .

${ }^{16}$ Stephen Kotkin uses the analytic notion of 'speaking Bolshevik' to refer to the language people spoke in the Soviet Union under Stalin, and how the ways in which they spoke about themselves became refracted through the lens of Bolshevism. I also find this notion useful to describe how Isaacs taught Britons to 'speak Kleinian' in everyday life. Stephen Kotkin, Magnetic Mountain: Stalinism as a Civilization (Berkeley: University of California Press, 1995).

${ }^{17}$ See Woolridge, op. cit. (note 6), 111. See also other references in note 6.

18 See Laura Cameron and John Forrester, 'Tansley's Psychoanalytic Network: An Episode Out of the Early History of Psychoanalysis in England', Psychoanalysis and History, 2 (2002), 189-256.

${ }^{19}$ Pines, op. cit. (note 10); Gardner, op. cit. (note 6), 15-36.
} 
Early in her career, Susan Isaacs supported the idea that psychology was a branch of biology. Her formal education at Manchester and Cambridge persuaded her that psychology must be in harmony with evolutionary theory. ${ }^{20}$ In addition, like the educational psychologist Cyril Burt, she was an advocate of measurement as a tool for understanding mental development and supported the idea that different children have different 'mental ages'. Isaacs was also a supporter of Jean Piaget's theories on the intellectual development of children and of progressive education as expounded by John Dewey. Inspired by both, she worried that disciplinarian teaching destroyed children's mental curiosity. She believed that children should be encouraged to educate themselves in accordance with their own particular capacities, rather than being forced to learn a pre-determined set of topics. ${ }^{21}$

Isaacs was given a striking opportunity to put such theories to the test when she was hired by Geoffrey Pyke to work at the experimental Malting House School in Cambridge from 1924 to 1927. Pyke, a successful speculator on the Metal Exchange, became interested in progressive education and psychoanalysis due to his own experiences as a Jewish boy who had been subjected to anti-Semitic bullying in school, and his desire to ensure that his son would not suffer the same fate. ${ }^{22}$ Pyke established the Malting House School on the progressive principle that young children should be stimulated to discover knowledge for themselves through play. Under Isaacs' and Pyke's guidance, the staff were instructed to suspend their authoritarian education methods and instead encourage the children's own inquiry into the world around them. ${ }^{23}$ Accordingly, a permissive discipline was established in this 'open-air laboratory'. ${ }^{24}$ There was plenty of garden space and equipment (donated mainly by professional and academic families) with which the children could explore the physical world, the ways things are made, and the manner in which they break apart. ${ }^{25}$ In the spirit of eclecticism that characterised other Cambridge (and English) scholars who were early enthusiasts of psychoanalysis, Isaacs and Pyke blended Kleinian psychoanalysis (with its emphasis on play and inner life further elaborated below) with other progressive ideas. ${ }^{26}$ For Isaacs, the school served as a scientific experiment. After it closed down, she used the Malting House data in her books, which had lasting impact on child education. ${ }^{27}$ On the basis of these publications, she was appointed the first Head of the Department of Child Development at the Institute of Education in London, where she trained other professionals. ${ }^{28}$

Isaacs' work with the children at Malting House School gradually made her critical of Piaget, and she eventually rejected many of his ideas. For example, she published a critique against his over-schematic stages of development, and his way of thinking about 'the child' in the abstract, rather than about the diverse individual needs of real children. ${ }^{29}$ In contrast

\footnotetext{
${ }^{20}$ Susan S. Brierley, An Introduction to Psychology (London: Methuen, 1921), 1-7, 42.

${ }^{21}$ Woolridge, op. cit. (note 6), 111-14.

22 David Lampe, Pyke: The Unknown Genius (London: Evans Brothers, 1959), 30.

23 Susan Isaacs, Intellectual Growth of Young Children (London: Routledge, 1930), 14-50.

24 Cameron, op. cit. (note 6), 853.

25 Philip Graham, 'Susan Isaacs and the Malting House School', Journal of Child Psychotherapy, 34, 1 (2008), $8-9$.

26 Cameron, op. cit. (note 6), 853.

${ }^{27}$ Isaacs, The Intellectual Growth, op. cit. (note 9) and the more Kleinian book: Isaacs, Social Development, op. cit. (note 9).

${ }^{28}$ Graham, op. cit. (note 25), 21.

${ }^{29}$ Susan Isaacs, 'Review of Piaget's The Child's Conception of the World', Mind, 38, 152 (1929), 506-13.
} 
to Piaget, Isaacs' main observation from her school work was that children's thought mechanisms are not entirely different from those of adults. They know less than adults and they have less developed minds, but they do not understand the world in radically different ways from adults. Children are therefore able to provide more sophisticated explanations of causation than Piaget had suggested. ${ }^{30}$

Importantly, Isaacs' work at the Malting House School coincided with her growing commitment to Kleinian psychoanalysis. Isaacs believed that the theories of Sigmund Freud, rather than those of Dewey or Piaget, enabled her to penetrate more deeply into the minds of children, and to study their intellectual development as well as their emotional and family life. After Melanie Klein visited the school in 1925, Isaacs was committed to her theories. ${ }^{31}$ Pyke, too, was impressed with Klein's ideas, ${ }^{32}$ and regulations at the school were adjusted on the basis of Klein's advice. By the time the psychoanalyst James Strachey visited the school, it was acquiring a negative reputation as a psychoanalytic institution focused on child sexuality. ${ }^{33}$ He reported that children were running wild and were free to kick one another, poke sticks in each other's eyes, and even spit in Isaacs' face. ${ }^{34}$ In response, Klein suggested to Isaacs and Pyke that absolute freedom was too frightening for young children. Accordingly, the staff adopted a different method, based on working together with their pupils to explore the outside world, and to balance what Klein saw as the children's disturbing 'inner life'. ${ }^{35}$

Melanie Klein (1882-1960) was one of the founders of child psychoanalysis. Born in Vienna of Jewish heritage, she developed a theory of psychoanalysis that emphasised unconscious aggression and its role in promoting anxiety in young children. Klein pioneered the technique of analysing children through interpretation of their play. According to Klein, children's play could be equated with adult free association in analytic treatment, and she ascribed complex symbolic meaning to every play gesture. Klein believed that the Oedipus complex, which she attributed to an age two years earlier than Freud, should be analysed deeply and conveyed to children, without fear for their psychological fragility. ${ }^{36}$ The analysis of play should be thorough in order to discover unconscious conflicts and negative emotions. Klein paid less attention to whether the environment was uncaring, and focused instead on the children's anxieties. She believed in the existence of a rich, inner psychological life, comprised of contradictory 'good' and 'bad' 'internal objects' representing, in part, conflicted feelings of love and hate towards the parents. She argued that unconscious 'phantasies', related to internalised projections of good and bad in the self or the parents, could give rise to extreme feelings of guilt and anxiety, even in young children. ${ }^{37}$ These feelings could manifest themselves

\footnotetext{
${ }^{30}$ Woolridge, op. cit. (note 6), 121-3.

31 Woolridge, op. cit. (note 6), 114-15. In 1921, this was one of the only children's schools in the world to gather inspiration from psychoanalysis. Cameron, op. cit. (note 6), 852. During the Second World War, Klein lived with Isaacs in Cambridge, where Isaacs conducted her important study on the psychological effects of evacuation. Isaacs was also a key supporter of Klein during the Anna Freud-Melanie Klein Controversial Discussions. Cameron op. cit. (note 6), 853.

32 Cameron op. cit. (note 6), 867-8; Graham, op. cit. (note 25), 7.

${ }^{33}$ Rickman, op. cit. (note 12), 281-2.

34 James Strachey's letter from February 17 1925, in Perry Meisell and Walter Kendrick (eds), Bloomsbury/Freud: The Letters of James and Alix Strachey, 1924-5 (London: Chatto \& Windus, 1986), 205; Woolridge, op. cit. (note 6), 117-18.

35 Cameron, op. cit. (note 6), 867; Woolridge, op. cit. (note 6), 119.

${ }^{36}$ Melanie Klein, 'Symposium on Child-Analysis', International Journal of Psycho-Analysis, 8 (1927), 339-70.

37 The word 'phantasy' in Kleinian psychoanalysis refers to the mental representation of aninstinct; it is also the
} 
in aggressive, destructive or cruel behaviour, or in fear of one's own destructiveness. They could also be expressed in jealousy, greed and phobias, or in symptoms such as night terrors, nail-biting, spitting or kicking. Klein believed there was a complex interplay between the child's inner phantasies and real experiences and relationships. Feelings of love and hate towards oneself or the environment could be reversed quickly, and so could feelings about 'goodness' or 'badness' in oneself or one's caregivers. Thus, behaviour that was inexplicable, maladjusted, delinquent, anti-social or disobedient could be revealed as symptomatic of internal emotional conflict. This was an important theory in seeking to explain the troubled behaviour of disturbed, delinquent or 'pre-neurotic' children at the time. ${ }^{38}$ Increasingly, it helped move professional attention away from hereditary notions of pre-disposition to physical or mental illness and towards the effect of the child's home on his/her emotional health. ${ }^{39}$ In Isaacs' Kleinian writings, thumb-sucking, stammering, bed-wetting, over-sensitivity, lying, feeding problems, temper tantrums and aggressive behaviour all became indications of internal conflict.

By the late 1920s, Isaacs' writing clearly reflected her increasing adherence to Kleinian ideas; indeed, she helped disseminate Klein's views on the inner emotional life of children. For example, in her 1928 paper 'The Mental Hygiene of the Pre-School Child', Isaacs discusses the relationship between external factors and the inner workings of the mind, quoting Klein as an expert in exploring 'the fixation and the time at which these fixations became connected with experience'. ${ }^{40}$ In The Nursery Years (1929), a popular book among parents, Isaacs introduced Klein's ideas by urging mothers and nurses to replace tradition with science. While many other writers at the time used psychoanalysis only selectively, focusing on the unconscious yet neglecting sexuality and aggression, Isaacs' Kleinian book discussed difficult topics like masturbation and violence in children. Isaacs asked caregivers to understand children's inner reality before punishing them. Opposed to conditioning children like a Pavlovian dog (research which influenced behaviourist writing), Isaacs argued for parenting solutions suited to the individual child's needs. ${ }^{41} \mathrm{Her}$ book also offered an innovative fusion of developmental psychology and psychoanalysis. Her definition of early life is distinctly Kleinian: the young infant has powerful wishes, feelings and phantasies, in stark contrast with earlier pedagogic notions of children as innocent. Isaacs believed children experience violent emotions like anger, jealousy and guilt, which cause temper tantrums and phobias - all of which are common and treatable through patient care. Influenced by Klein's technique of analysing a child's play, Isaacs characterised play as children's work which permitted exploration and healthy emotional expression. $^{42}$

basic unconscious stuff of all mental processes. See Elizabeth Bott Spillius, 'Developments in Kleinian Thought: Overview and Personal View', Psychoanalytic Inquiry 14 (1994), 324-64; Susan Isaacs, 'The nature and function of phantasy', op. cit. (note 13).

38 Sarah Haynes, "Rabbits and Rebels": the medicalisation of maladjusted children in mid-twentieth century Britain', in Mark Jackson (ed.), Health and the Modern Home (London: Routledge, 2007), 141-2.

${ }^{39}$ Ibid., 142.

${ }^{40}$ Quoted in Graham, Susan Isaacs, op. cit. (note 6), 191.

${ }^{41}$ Isaacs, The Nursery Years, op. cit. (note 10). See Isaacs' critical review of Watson's habit psychology in Susan Isaacs, 'Some notes on the Prevalence of Neurotic Difficulties in Children', British Journal of Educational Psychology, 2 (1932), 71-91.

42 Isaacs, The Nursery Years, op. cit. (note 10). See also essays by Susan Isaacs on 'Habits' and by Melanie Klein on 'Weaning' in John Rickman (ed.), On the Upbringing of Children (London: Kegan, Paul, Trench \& Trubner, 1935), 123-66 and 31-6. On the history of early psychoanalysis and the invention of play technique, see Claudine and Pierre Geissmann, A History of Child Psychoanalysis (New York: Routledge, 1998), 109-33. 
Kleinian psychoanalysis, as popularised by Isaacs, should be viewed together with competing early twentieth-century theories. During the inter-war period, the number and scope of publications on childcare expanded significantly, and knowledge of child health and development became specialised. Much of this literature focused on the deviant or abnormal child and on preventing delinquency among the working classes. Increasingly, however, popular scientific literature began discussing the so-called normal child, prescribing new parenting standards, regardless of class, which would ensure the physical and emotional health of children. The focus of these texts shifted from a hygieneoriented emphasis on children's bodies to their minds, fantasies and emotions. ${ }^{43}$ By disseminating new knowledge on the pre-school child, Isaacs was central in facilitating this psychological shift.

After the First World War, texts offering parenting advice increasingly sought to address all the nation's children - 'normal' and 'abnormal', rich and poor - employing expert language drawn from scientific observation and research in the process. Earlier in the century, the main goal of literature that advised on childcare was to limit infant mortality. The writings of New Zealand doctor Frederic Truby King, which were popular in Britain before the war, advocated a regulated, scientific system for infant feeding, designed to promote health. His book Feeding and Care of Baby called upon mothers of all classes to recognise child-rearing as a matter of national rather than personal concern. $\mathrm{He}$ recommended absolute regularity in feeding and toilet training, and an abundance of cool air, cold baths and clean water from birth. According to Truby King, irregularity during infancy led to disease, degeneracy and disorderly conduct in adulthood; parents were thus warned against causing irreversible damage. This hygienist literature was supplemented by behaviourist texts, such as those by the American John Watson, who also stressed absolute regularity. Watson also warned against excessive maternal love which might spoil the child; this drew on a nineteenth-century evangelical dictum that spoiling leads to damnation. New scientific literature tied its old-fashioned emphasis on discipline and regularity to modern medicine, social welfare and a newly secular concern with the behaviour and mental health of children. ${ }^{44}$

And yet, in the inter-war period, psychoanalytic literature began challenging these disciplinary practices. Moreover, it offered a model of mutual understanding between child and parent as an alternative to the strict parental authority advocated by behaviourists. Indeed, during the 1920s, an approach called 'New Psychology' emerged, selectively influenced by Freud's ideas regarding the unconscious. Advocates of New Psychology and educational psychology in Britain defied the notion that child behaviour should be controlled and conditioned. Instead, indirectly informed by Klein's ideas, they believed children's actions were influenced by emotional complexes and conflicts. These advocates recognised aggression, violence and psychological volatility as natural aspects of the human condition, an idea which gained popularity after the First World War. Emerging experts like Cyril Burt, Emanuel Miller, Hugh Crichton-Miller and Margaret Lowenfeld were interested in children's problems such as nervousness, phobias, temper tantrums and destructive behaviour. Their work was enthusiastically read by parents and caregivers.

\footnotetext{
${ }^{43}$ Cathy Urwin and Elaine Sharland, 'From bodies to minds in childcare literature: advice to parents in inter-war Britain', in Roger Cooter (ed.), In the Name of the Child: Health and Welfare in England, 1880-1940 (London: Routledge, 1992), 181-8.

44 Ibid., 176-80; Truby King, Feeding and Care of Baby (London: Macmillan, 1913); J. B. Watson, Psychological Care of the Infant and Child (London: Allen \& Unwin, 1928).
} 
Among these experts of the inter-war period, Susan Isaacs was the most influential in promoting a Kleinian psychoanalytic approach to child-rearing. ${ }^{45}$ Her writings proposed that caregivers should adopt the child's point of view when trying to understand children's emotions. She argued that this personal approach could contribute to the stability of the nation's democracy.

The emergence of the Child Guidance Movement in the inter-war years also contributed to the new interest in children, in ways that were similar to and yet distinct from Isaacs' views. Child guidance was a clinic-based form of psychiatric medicine, advocating that mental maladjustment was to be tackled through observation and treatment in the home. ${ }^{46}$ The increasing emphasis on the home afforded significant opportunities for psychiatric work and its claims to 'scientific' knowledge in preventing mental disorder and fostering a healthy environment for the normal child. Child guidance emphasised teamwork between psychiatrists, psychologists and psychiatric social workers. Overall, child guidance was viewed as a branch of medicine rather than pedagogy or psychology. However, a lot of child guidance work was actually carried out in the home rather than the clinic, by visiting psychiatric social workers, ${ }^{47}$ on the assumption that there were really no problem children, only problem parents. ${ }^{48}$ Less emphasis was laid on the child per se, and more on the child in his or her domestic setting, thereby suggesting the parents as the cause of their children's difficulties. ${ }^{49}$ In the same vein, when Isaacs talked about 'the environment', she was usually referring to the home rather than to socio-economic circumstances. ${ }^{50}$ She also shared with the child guidance movement the principle of looking at both the children and their parents; however, she placed more emphasis on the inner life and individual characteristics of the child.

At times, Isaacs recommended that parents use child guidance services, but it can be said that instead of bringing the child guidance expert or social worker into the home, she brought expert knowledge to parents via her magazine columns. Furthermore, for her, the study of the child was more a branch of education and psychology, and less of medicine. ${ }^{51}$ While many child guidance experts were suspicious of psychoanalysis, and often disparaged in-depth discussion of the child's thoughts or sexuality, Isaacs was eager to delve into the child's mind. Like them, however, at times she also resorted to a more watered-down version of social work, or practical advice for household and family organisation. ${ }^{52}$

\footnotetext{
45 Urwin and Sharland, op. cit. (note 43). See also Deborah Thom, 'Wishes, anxieties, play and gestures: child guidance in inter-war England', in Roger Cooter (ed.), In the Name of the Child (New York: Routledge, 1992), 200-19.

46 John Stewart, "I thought you would want to come and see his home": child guidance and psychiatric social work in inter-war Britain', in Mark Jackson (ed.), Health and the Modern Home (London: Routledge, 2007), 111. On the professional development of English psychiatry see: Akinobu Takabayashi, 'Surviving the Lunacy Act of 1890: English Psychiatrists and Professional Development during the Early Twentieth Century', Medical History, 61 (2017), 246-69.

47 As argued by John Stewart, ibid., 113.

48 Ibid., 113.

${ }^{49}$ Ibid., 113-15.

${ }^{50} \mathrm{Ibid}$., 119. Sarah Haynes emphasised that contemporary medical notions of home and the domestic environment, however, encompassed many factors including sibling relations, play fellows or the media. See Haynes, op. cit. (note 38$), 139$.

${ }^{51}$ It should be noted that both Isaacs and Klein later believed that psychoanalysis and education should be differentiated because they are not one and the same thing. See Shaul Bar-Haim, op. cit. (note 6), 105-6, 108-9.

52 Stewart, op. cit. (note 46), 122.
} 
Medical notions of children's behavioural disorders changed significantly in this period. Medical professionals dedicated more studies to the concept of 'maladjustment' with the aim of identifying the causes of criminality. Similarly, their fears centred on the 'preneurotic' or 'delicate' child and, under the influence of Kleinian psychoanalytic theories, they placed greater emphasis on problems caused by unrecognised neurosis. ${ }^{53}$ Medical intervention was considered necessary as a preventative measure to protect society from the potential dangers of untreated disorders. Isaacs was less alarming than psychiatrists William Health, Cyril Burt or John Bowlby in her call for action, and yet at the same time, she contributed significantly to a more refined definition of, and much closer attention to, the behaviour of the pre-neurotic child. While the writings of the time often adopted a critical tone when discussing the maladjusted as those who did not adapt to dominant standards of social behaviour, Isaacs was more forgiving and addressed the problems of parents as well as those of their children in her columns. ${ }^{54}$

It is noteworthy that Isaacs wrote her magazine columns during a time when childcare had become more professionalised, and scientific curricula were being developed for nursery nurses and nannies. When she began writing about childcare, health visitors were required for the first time to hold a Health Visitor's Certificate. The professionalisation of nannies and health visitors was part of a larger development of child-rearing knowledge grounded in scientific evidence. Parents of all classes, especially mothers, were held to higher standards. Psychoanalytic writers were quick to accuse parents of mistreating their children and causing their nervous disorders. Crichton-Miller, for example, urged parents to acquire the 'right' knowledge, namely psychoanalysis. Crichton-Miller introduced the application of psychoanalytic notions like 'transference' and 'projection' in analysing children's problems. By contrast, Isaacs employed encouraging, positive language, adopting a more respectful, modest tone. Responding to confused mothers and nurses who sought her knowledgeable, expert advice, she wrote about the best ways to approach family predicaments. With her clear writing style and vast experience as an educator working closely with children, parents and nurses, her advice was practical and level-headed. Her sympathy for parents further set her apart from other writers, and contributed to her popularity. The Nursery Years, was expanded in a second edition in 1932, and reprinted nineteen times by 1971 , selling around 100000 copies. ${ }^{55}$ With four reprints in the interwar period, the book helped shift the preoccupations of parenting away from problems of handling, towards questions of meaning; consequently, parents became interpreters of their children's minds. They began developing more equal relationships with their children, based on communication rather than authority. As an expert, Isaacs eschewed a prescriptive approach, advocating instead that parents and nurses reflect on their children using Kleinian psychoanalysis, thus redefining parental roles as sympathetic rather than disciplinarian. ${ }^{56}$ In her Ursula Wise columns, she encouraged caregivers to observe and learn from children's play.

\footnotetext{
53 On the concern for 'psychological rebels' vs 'psychological rabbits', see Haynes, op. cit. (note 38), 129-52; on Klein, 141-2, 146.

54 Ibid., 132-41; 142-7 and my analysis below.

55 Graham, op. cit. (note 6), 197-202.

56 Urwin and Sharland, op. cit. (note 43), 185-8.
} 


\section{Ursula Wise: Introducing Psychoanalysis to a Popular Audience}

Isaacs began her regular column as Ursula Wise in the magazine Nursery World in 1929. The magazine, which sold for twopence a copy, was the only weekly at the time targeting trained children's nurses and nannies working in middle-class households. The letters in Nursery World came from nurses and parents (predominantly mothers). The editors assumed that middle-class mothers purchased and read the paper, and then passed it on to the nurse. In fact, mothers sent five times more letters to Ursula Wise than nurses, suggesting that most readers were mothers. A decline in employed nurses in the $1930 \mathrm{~s}$ reinforces this conclusion. The column's readers, therefore, consisted of middle-class mothers and the more educated nurses. ${ }^{57}$

Isaacs wrote approximately 3000 words a week and the magazine paid her around two guineas per thousand words - a substantial income at the time. Initially, the magazine suggested the pseudonym Jane Strong, which Isaacs rejected due to its authoritarian implications, preferring Ursula Wise instead. ${ }^{58}$ When Isaacs began writing in 1929, Nursery World encouraged readers to write to her: 'If you would like advice about any difficulty in dealing with your child's behaviour, write to Miss Ursula Wise. . . giving your initials or pseudonym, and she will answer your problem through these columns. ${ }^{59}$ By 1932, the magazine altered the wording, emphasising Isaacs' psychological expertise: 'If you would like the advice of an expert child psychologist on any problems with your child's behaviour write to Ursula Wise. .. ${ }^{60}$ Indeed, by then, parents perceived the problems they wrote about as being mostly psychological in origin. ${ }^{61}$ Below, I trace Isaacs' gentle introduction of psychoanalytic concepts to her readership. Thereafter, I will show how she argued against the behaviourist approaches of her contemporaries and, finally, how she led her readers towards a child-centric understanding of their roles as parents and caregivers.

In her columns, Isaacs set out to familiarise readers with psychoanalysis, and its basic ideas and language, while also strengthening the authority of its trained experts. Acting as a mediator between the intellectual ideas of clinical psychoanalysis and the broader public, Isaacs addressed her readers with an approachable tone, simultaneously offering the knowledgeable advice of a specialist and the understanding of a peer. Striking this balanced tone allowed Isaacs, as Ursula Wise, not only to introduce the continental, innovative ideas of Klein, but also to encourage readers to use psychoanalytic language, and to think like psychoanalysts themselves. At the same time, Isaacs was careful to emphasise that true expertise remained the domain of experts. The readers were thus trained in the fundamental ideas of psychoanalysis, while learning to respect its authorities, and ready to turn to them when their own understanding fell short.

This complex balance is clearly displayed in a column from 25 June 1930, in which mothers and nurses wrote about their children's difficult behaviour. ${ }^{62}$ Here Isaacs introduces a key term, 'neurosis', already popularised during the Great War in relation

\footnotetext{
57 According to Graham, op. cit. (note 6), 207-9.

58 Ibid., 207-9.

59 See for example, Susan Isaacs, 'Nervous Habits', Nursery World, 27 August 1930, 432.

${ }^{60}$ Susan Isaacs, 'The Nervous Child', Nursery World, 29 June 1932, 142.

${ }^{61}$ For example, a nurse of a boy who turned his toes in was told by Isaacs to consult expert advice about remedial exercise. See Susan Isaacs, 'The Nervous Child', Nursery World, 29 June 1932, 141-2.

62 On the 'problematic child', see: Stewart, op. cit. (note 46); Haynes, op. cit. (note 38).
} 
to shell-shocked soldiers. ${ }^{63}$ One mother described a 5-year-old boy who had developed a habit of blinking, screwing up his eyes every few minutes and twitching his arms. Another mother's letter described a 2-year-old girl who suffered from nightmares, which caused spasms during the day. In her response, Isaacs introduced Klein's psychoanalytic ideas. These children, she wrote, belong to the category of 'the real problem child', and are 'the kind that psychologists term neurotic'. While caregivers expect normal children to be a little disobedient, or shy with strangers, it was assumed that there must be 'some deep trouble' underlying persistent anger and defiance that have no apparent cause. Isaacs argued that the cause lies 'far below the surface of the child's mind, and [has] little to do with real events'. These extreme cases, she wrote, call for the help of experts. ${ }^{64}$

In columns dedicated to fears, phobias and phantasies, Isaacs laid out Klein's ideas. In one example, the parent of a boy aged 2 years and 4 months described how seemingly random events caused him to grow pale with fear. Isaacs explained that the boy's fear was irrational, and stemmed from 'some inner sensitivity of the child'. For Isaacs the Kleinian, the boy clearly suffered from unconscious phantasies. Writing as Ursula Wise, however, she suggested some practical, simple advice: offer the boy calm sympathy, keep him away from things which frighten him, and do not give his fears much attention. ${ }^{65}$

Another parent described a 2-year-old who had recently become nervous, and who after wetting himself unexpectedly said: 'Don't smack me mummy.' The mother admitted: 'I am so anxious that he should have "nerves", and think if I can check these little ways of his early early [sic] I may save these leading to bigger problems. ${ }^{66}$ She further described how the boy disliked being called naughty, demanding assurance that he was good. While this description surely offered an opportunity for Kleinian analysis (ie. that the boy feared the outside world because he felt a badness in himself), Isaacs offered only practical advice, saying that although the boy was obviously over-sensitive, making a fuss of his behaviour might encourage him. She recommended replacing scolding with a calmer response. ${ }^{67}$ This example illustrates Isaacs' deft use of both professional psychoanalytic language and common-sense advice. ${ }^{68}$

Isaacs did not always shy away from offering overtly Kleinian advice. As her relationship with her readers developed, she used Klein's language more freely. One parent admitted that although Isaacs' attitude of calm cheerfulness often helped her with her own boy, who was afraid of an imaginary biting creature, she struggled to maintain it. Isaacs then offered a more theoretical approach, suggesting the boy's fear brought to mind the biting of an infant expressing anger. This interpretation reflected Kleinian ideas of inner badness, and indeed, Isaacs explained the boy was frightened by 'his own naughty self'. He wanted to be good, but feared he was bad, and might bite. His problem, then,

\footnotetext{
${ }^{63}$ See Ben Shephard, A War of Nerves: Soldiers and Psychiatrists in the Twentieth Century (Cambridge, MA.: Harvard University Press, 2001), 21-32.

${ }^{64}$ Susan Isaacs, 'Ursula Wise Writes about the Real Problem Child', Nursery World, 25 June 1930, 111. In another case, a mother wrote about her fear that her boy of seven and a half, sensitive, poor at sport and full of nervy ticks, might turn into a 'cry-baby' and become a laughing stock at school. Isaacs confirmed that he is indeed 'neurotic in type' and needs psychological treatment. See Susan Isaacs, 'Sensitive or "Nervy", Nursery World, 18 February 1931, 405-6.

65 Susan Isaacs, 'Fears and Phobias', Nursery World, 15 October 1930, 671-2.

66 Susan Isaacs, 'Sensitive or "Nervy”, Nursery World, 18 February 1931, 406.

${ }^{67}$ Ibid., 406.

${ }^{68}$ See also Susan Isaacs, 'Fears and Phobias', Nursery World, 15 October 1930, 672.
} 
stemmed from 'inner difficulties'. Thus, Isaacs made Klein's notion of a good and bad self more broadly accessible. ${ }^{69}$

A column from 30 August 1933 was titled 'Tempers \& Tantrums: violent tantrums present one of the most acute problems of handling children between two and three years old' ${ }^{70}$ Here, a 'most anxious' mother of a boy of three and a half complained of terrible tantrums, and his nurse's difficulty addressing them. Tantrums, Isaacs explained, are outbursts of emotion and require experienced, trained handling. Inexperienced nurses respond with unhelpful fear and shame. Isaacs sympathised with the nurse but recommended an older nanny instead. Violent tantrums, she assured readers, are a normal phase in children's development. Presenting an explicit Kleinian view, she suggested aggression is a normal part of childhood and requires careful emotional handling. ${ }^{71}$

The discussion of aggression continued the following week. A boy of 22 months developed the dangerous and expensive habit of throwing things, thereby frustrating his parents. Isaacs described the boy's problem as acute, causing great practical difficulty. Questioning his care, Isaacs wrote that although his behaviour might seem 'wholly and exasperatingly destructive', it nevertheless has 'a true developmental meaning'; he is dealing with 'his own special problems of feeling and of skill'. Such advice helped parents to encourage their children develop more positive skills. ${ }^{72}$

Themes of fear and anxiety continually loomed large in Isaacs' columns. In one dedicated to 'Nervous Children', Isaacs continued transmuting Klein's ideas into accessible advice. A reader called 'Reason', described a 7-year-old who dreaded anything grotesque or unnatural. To a Kleinian thinker, this would relate to the anxieties and phantasies of childhood. But how was Isaacs to explain such a complex psychoanalytic idea? She replied that the child has 'an extremely interesting problem, and to unravel it fully would take us very deep indeed into child psychology, much further than space will allow'. ${ }^{73}$ However, she did propose that grotesque things clearly 'stir up some very deep and hidden fantasies in the boy's mind belonging to the earliest period of mental development in infancy'. ${ }^{74}$ Explaining Klein's ideas, Isaacs described the infant's helplessness before a strange and powerful world, unable to control or understand it. Thus, imaginary fears become prominent. For some children, these infantile terrors appear later: the grotesque things 'get below the surface' and stir unhappy terrors remembered from infancy. ${ }^{75}$

In Isaacs' columns, readers began to understand fears as 'phobias'. Reader 'Beatrice' wrote about a girl fearful of going downstairs. Her mother had fallen downstairs when the girl was a tiny baby. Isaacs described this as the phobia typical of a normal child, which is easily addressed with psychological treatment. She did not believe the girl's fear was related to the mother's fall and suggested instead that the mother was anxious about stairs and had communicated her fear to the child. Isaacs recommended expert advice but also

\footnotetext{
69 Susan Isaacs, 'Fears and Fantasies', Nursery World, 18 March 1931, 544-5.

70 Susan Isaacs, 'Tempers \& Tantrums', Nursery World, 30 August 1933, 405.

71 Ibid., 405-6, 423.

72 Susan Isaacs, 'A Destructive Child', Nursery World, 6 September 1933, 443-4, 448.

73 See, for example, Susan Isaacs, 'Nervous Children', Nursery World, 12 February 1930. Reprinted in Smith (ed.), op. cit. (note 6), 233.

74 Susan Isaacs, 'Nervous Children', Nursery World, 12 February 1930. Reprinted in Smith (ed.), op. cit. (note 6), 233. Isaacs was referring in this text to unconscious phantasies (with 'ph'), but as in her other popular writings, she often used the word 'fantasies' (with 'f'). See note 38.

75 Ibid., 233.
} 
suggested that the phobia may disappear altogether with time. ${ }^{76}$ Similarly, Isaacs described a girl's fear of rain following a thunderstorm as 'a typical phobia'. As in many cases, Isaacs reassured the parents, recommending treatment but also proposing that the phobia might disappear in time. ${ }^{77}$ The magazine offered the reassuring title: 'Growing up: the stages of growth from infancy to school days and from early school days to adolescence each have their problems. With all of these Ursula Wise is well qualified to help. ${ }^{78}$

In other cases, however, Isaacs insisted that 'treatment can only be carried on by experts', as in the case of a nervous child who feared many things, and screamed at night in terror. ${ }^{79}$ In another case, 'John's nurse' thanked Isaacs for her columns and described a boy of five and a half who was fearful of insects, insisting that a snail he had seen on the wall was a bee. A fear of bees is a childhood phobia, Isaacs assured her, and she used a picture book about insects to explain that there was nothing to fear. She added that although the fear may pass, the boy may yet remain rather nervous. ${ }^{80}$ Thus, Isaacs continually reassured letter-writers, while also encouraging them to trust the experts.

The editorial title of a column on 'Dislikes and Phobias' from 6 May 1935 read: 'Sudden and apparently unreasonable fears and dislikes often complicate the early years of childhood. They have a reason, but it is sometimes difficult to find...' A reader called 'Puzzled' wrote about her otherwise rational little girl who disliked her mother playing the piano, often crying when she did so. Isaacs confirmed the reader's connection between this piano phobia and teething problems. After all, Isaacs the psychoanalyst reasoned, the piano's ivory keys are not unlike the child's teeth. Isaacs suggested, as would Klein, that the child's anxiety was related to her teeth. Klein believed that children were fearful of harming their environment and that they projected these fears onto objects and people. As this example demonstrates, Isaacs encouraged readers to interpret behaviour psychoanalytically and to search for symbolic meaning. ${ }^{81}$

In a similar letter, a girl fussed over things being out of place, like her mother's untidy hair. Adopting Isaacs' psychoanalytic approach, the mother pondered the underlying reason for this behaviour. Isaacs agreed, 'there are certainly psychological reasons'. She explained: 'The child cannot bear to see things not quite in order because deep down in her own mind she is afraid that she may have caused such things to go wrong. She is afraid of her own destructive tendencies, which of course every child has....' Continuing this Kleinian line of thought, Isaacs added that it is not uncommon for a child's anxiety to manifest as fussiness. Here, Isaacs taught her curious and receptive audience that minor anxieties which may be difficult to explain often stem from deep internal fears of destructiveness.

Increasingly, parents wrote to Isaacs using explicitly psychoanalytic language. The mother of a boy who screamed with fear at the slightest scratch pre-emptively ruled out 'unconscious jealousy' of his brother, as the terrors began before the brother's birth, and the parents had prevented the development of a 'jealous complex'. Isaacs agreed that the boy was experiencing psychological difficulty and was not merely seeking attention: 'Sometimes it is the other way about: the important feelings about big events are expressed

\footnotetext{
${ }^{76}$ Susan Isaacs, 'Two Year Olds are often Cruel', Nursery World, 5 August 1931, 326.

77 Susan Isaacs, 'Is Your Child Excitable and Highly-Strung?' Nursery World, 7 October 1931, 617.

78 Ibid., 618.

79 Susan Isaacs, 'Fears and Phantasies', 7 January 1932, 293.

${ }^{80}$ Susan Isaacs, 'The Destructive Child', Nursery World, 15 June 1932, 74, 87.

${ }^{81}$ See Susan Isaacs, 'Dislikes \& Phobias', Nursery World, 6 March 1935, 493.
} 
in connection with some comparatively slight event, where in fact the feelings matter less and do less harm. ${ }^{82}$

Aggression in Isaacs' writings was often connected to jealousy and anti-social behaviour. The mother of a 22-month-old girl described her jealousy of her little brother and hostility to strangers. These feelings, Isaacs wrote, must frighten the little girl and conflict with her impulses for tenderness. She feared losing her mother's love if she showed her jealousy. ${ }^{83}$ The girl therefore turned her jealousy toward strangers. In this simple manner, Isaacs explained another important Kleinian idea to her readers, namely that love and hate are often experienced simultaneously. ${ }^{84}$ Further, Isaacs encouraged sympathy for the child's viewpoint and experience.

The nurse 'Petro' wrote about a willful 1-year-old girl who was very possessive of her belongings and also tended to hurt other children. Her parents feared that if given in to a nature so difficult, she will grow up to a bad-tempered, self-willed child, and be disliked by friends as are all spoiled children' ${ }^{85}$ Adhering to Klein's view that children are often aggressive, rather than innocent, angelic creatures, Isaacs advised against hitting, and recommended instead firm protest against hurting others. Isaacs referred to the Kleinian concept of 'inner aggression', which she believed might be reinforced by a harsh scolding. Isaacs juxtaposed this Kleinian analysis with an endorsement of firm and loving parental handling. ${ }^{86}$

Isaacs' amiable tone established a far more equal, democratic footing between her as a doctor and those who sought her advice. This is clear in her response to the nurse of a 4-year-old girl who was prone to screaming when upset. Isaacs wished she could offer advice, but could only say that the girl was 'a very nervous child'. She advised the nurse not to blame herself, even if a calm approach was unsuccessful, and that patience would ultimately ease the child's 'inner difficulties' and enable development. Isaacs warned the nurse that she could not cure the child, but that if she was happier, the child would be too. ${ }^{87}$ As an expert, Isaacs showed sympathy for parents and nurses, thus winning their admiration. Her willingness to refer them to other experts earned their respect. ${ }^{88}$ Most often, she reassured caregivers that problems were normal and would most likely disappear.

Many letter-writers expressed their appreciation of the column and Isaacs' psychoanalytic advice, which taught them the hidden dynamics of childhood. The letters of caregivers demonstrate that psychological language and thinking were incorporated into their practice, often as a result of Isaacs' responses. For example, a letter from 'M.P.' described a girl who was fearful of certain Bible stories, and expressed concern that this might

\footnotetext{
${ }^{82}$ Susan Isaacs, 'Fear and Fussiness', Nursery World, 22 April 1936, 810, 819.

83 Susan Isaacs, 'Jealousy is often the Cause of Tempers \& Tantrums', Nursery World, 8 July 1931, 197.

${ }^{84}$ See also the popular book Melanie Klein and Joan Riviere, Love, Hate and Reparation (New York: Norton, 1964).

85 Susan Isaacs, 'Jealousy', op. cit. (note 83), 198.

86 Ibid., 198.

${ }^{87}$ Susan Isaacs, 'The Nervous Child', Nursery World, 29 June 29, 1932, 141.

88 In 'Is Your Child Excitable and Highly-Strung?', the mother of an 8-year-old girl described her as a very excitable child who also stammered. Isaacs answered in a way that revealed her optimistic and almost naïve trust in experts. All experts on stammering, she said, are agreed that fixing on the child's stammering will make it worst. The best is to leave the child alone and seek a specialist's advice and proper treatment. She expressed confidence that they would certainly help the child. Susan Isaacs, 'Is Your Child Excitable and Highly-Strung?' Nursery World, 7 October 1931, 617.
} 
become 'a complex'. ${ }^{89}$ Another woman wrote about her child's 'hysteria' when going to the dentist. ${ }^{90}$ Meanwhile, 'J.P.' wrote of her interest in child psychoanalysis.

I have always found your weekly articles most interesting - your advice to others has helped me to be on the alert for various developments and phases in my own child. Indeed some of the so-called 'tiresome ways' of a child become much less trying if they are studied as psychological - or physiological - problems. It helps one to take a broad view beyond the annoyance or disappointment of the moment.

When describing a girl who would smack people for no reason, the writer added, 'I am really more interested [in hearing Isaacs' answer] than anxious. ${ }^{91}$

\section{Against behaviourism and for democracy}

In her magazine columns, Isaacs situated her Kleinian psychoanalytic ideas in direct opposition to behaviourism. She openly criticised popular British childcare methods which relied on discipline, conditioning habits, obedience and corporal punishment. Corporal punishment, in particular, had already come under criticism in the late nineteenth century, thanks to voluntary societies like the National Society for the Prevention of Cruelty to Children; Isaacs brought the critique into the twentieth century. The behaviourist John Watson recommended corporal punishment and negative conditioning in immediate response to bad behaviour. Isaacs, by contrast, believed punishment aggravated the child's anxiety, and she recommended a more caring, empathic approach instead. The question of children's fear caused similar disagreement between behaviourists and psychoanalysts. Watson blamed parents for their child's bad behaviour, neurosis and fears, and argued they should be remedied with routine and discipline. Isaacs focused on understanding the source of the fearful child's psychology in order to understand the source of the fears. Like Klein, Isaacs argued that even gentle parents could appear negative and frightening in the child's imagination. Moreover, whereas Watson contended that all children should be conditioned in the same way, Isaacs made frequent reference to individual and inherited tendencies, and the need to accommodate each individual child's needs. Watson viewed the institution as an ideal environment for children, far superior to the home; Isaacs, however, viewed the affection between child and parent as key to the child's mental development. ${ }^{92}$

The letters of parents and nurses reveal a growing dissatisfaction with older practices, as they sought advice grounded in Kleinian psychoanalysis. The reader 'J.M.F.' wrote to Isaacs about a 3-year-old boy who was in her care while his mother was in hospital, and who repeatedly wet himself. J.M.F. wrote: 'I never punish him, of course, and always praise him whenever there is any improvement...' The interesting phrase here is 'of course', signifying how much had changed in inter-war Britain. 'Bad behaviour' was no longer immediately punished. In this time of transition, however, the nurse was unsure of the right response, asking Isaacs whether she should hold the boy out and make him water, as recommended by the behaviourists. The writer emphasised that the boy was 'a normal, healthy kiddie, and a very good little nab except for this'. In typical Kleinian form, Isaacs advised against scolding, as increased anxiety would only lessen the child's control. She advised the caregiver to ensure the child knew that she did not think badly of him. ${ }^{93}$

\footnotetext{
${ }^{89}$ Susan Isaacs, 'Fears and Phobias', Nursery World, 15 October 1930, 686.

90 Susan Isaacs, 'Fear of Bodily Hurt', Nursery World, 30 May 1944, 959.

91 Susan Isaacs, 'Tantrums and Tempers', Nursery World, 24 September 1930, 567-8.

92 Graham, op. cit. (note 6), 210-16; Urwin and Sharland, op. cit. (note 43), 180.

93 Susan Isaacs, 'Nervous Habits by Ursula Wise', Nursery World, 27 August 1930, 431.
} 
Another letter further demonstrates the shift away from hygienist and behaviourist approaches toward psychological solutions. 'C.A.G.' wrote of a child of 20 months who had been raised according to Truby King's curriculum of regularity. After a bad fall 'upset his nerves', the child became fussy with food and prone to tantrums. Isaacs counselled that the child should eat at his own pace without coaxing. She attributed the tantrums to the sudden loss of the child's nurse, and pointed to the work of herself and others for further information. ${ }^{94}$ In another case, a girl of 17 months refused to sleep in her cot. Exercise in the open air had not helped, and the mother asked whether she should strap the girl into the cot. Isaacs strongly opposed strapping the child in, asking whether the process of teething was a possible cause instead, since her research showed it often frightened children. ${ }^{95}$

While behaviourists believed affection towards children would cause them to be spoiled and unruly, Isaacs believed love and care were paramount in raising emotionally-balanced children. A nurse, 'anxious to do the best possible' for the children in her care, described a boy with a violent temper who refused to go to bed. The nurse initially reacted with firmness, as she did not want him to turn into a 'mammy coddle' - a concern which had worried Watson when warning against warmth. Isaacs condoned a firm approach in moments of struggle, but an overall demeanour that is 'as friendly and cheerful and affectionate as possible'. The message was that proper handling - psychoanalytic attention to their needs paired with kindness - would enable children to grow out of these turbulent phases. ${ }^{96}$ In the case of a child who emigrated away from England and experienced a difficult weaning, Isaacs stressed 'warm and unequivocal signs of love' instead of attempting 'to discipline and train him'. ${ }^{97}$

In her columns on aggression, Isaacs argued for individual character and against the universal rules espoused by behaviourists. The reader 'Beke', who liked one of Isaacs' responses, wrote about a boy who wet himself at night. The mother employed a system of regularly taking him to the pot at $10 \mathrm{pm}$. But the boy resented this practice and 'screamed the house down'. Exasperated, the mother let him sleep wet. She wondered how she could train him. 'I need hardly say that he is not scolded', she mentioned, revealing that the new focus on understanding the child had slowly replaced methodical discipline. ${ }^{98}$ In this column and others, Isaacs presented her expert voice with delicate subtlety. She began by unpretentiously admitting the difficulty of the problem, since common sense suggests that the child cannot hold his urine for the night. Yet, drawing on her expertise, she encouraged flexibility: leaving the boy with a wet diaper for a while, speaking with him, and only then lifting him. ${ }^{99}$ Isaacs thus implied that asking the child to express his needs, and demonstrating a willingness to accommodate them, would prove more effective than strict adherence to the behaviourist system.

In her columns on anxiety and fear, Isaacs repeatedly wrote against rigidity, and by implication against behaviourism. To the parents of a teething child fearful of being left alone, she wrote: 'I do not think that anyone who is not hidebound by rigid theory would say that you must leave him to cry without ceasing for over an hour day after day....' She also wrote against the practice of leaving children of two and three alone: 'My own view

\footnotetext{
94 Ibid., 431-2.

95 Susan Isaacs, 'Jealousy', Nursery World, 29 March 1930, 594.

96 Susan Isaacs, 'Tantrums and Tempers', Nursery World, 24 September 1930, 567.

97 Susan Isaacs, 'Unkindness and Greed', Nursery World, 27 November 1935, 960.

98 Susan Isaacs, 'The Destructive Child', Nursery World, 15 June 1932, 88.

${ }^{99}$ Ibid., 88.
} 
is that they should certainly be encouraged to be independent of grown-ups for a part of their day, but that allowances have to be made for individual temperaments. ${ }^{100}$

In the 1920s and 1930s, Isaacs, like other psychoanalysts at the time, related child psychoanalysis to another goal, that of educating for democracy. This, she believed, was an emotional and a psychological task, which could strengthen democratic values like cooperation, adherence to principles of fairness, mutuality, social responsibility and independence of thought. Consent, dialogue, equality and agreement should replace strict familial roles and, by extension, social hierarchy. Psychoanalytic education sought to shape productive, social and non-violent members of society. The values of progressive, analytic child-rearing were believed to counteract the rise of totalitarian regimes. Proper care in childhood could therefore form an ideal democratic adult. ${ }^{101}$

As I have shown elsewhere, psychoanalysts were essential in explaining the kind of selfhood required of democratic citizens (this is rarely remembered when their writings are read today). I have argued that our basic notions of a normal self within a democratic society, and the idea that democracy requires maturity and a certain level of mental health stemming from a healthy childhood, were developed in twentieth-century Britain by writers like Isaacs. Psychoanalysts hoped that addressing the problem of human aggression and anxiety would enable individuals to maintain a just, peaceful society. The answer to challenging emotional behaviour, analysts believed, was linked to loving family relations and a healthy childhood. They argued that plans and social policies for a better world had to address family relations and take into account the psychological relations between external and internal aggressive realities in order to guarantee the maintenance of peace. Thus, contemporary thinking about the basis of the welfare state was mobilised not only by social and economic principles but also by psychological insights. ${ }^{102}$

Isaacs argued in her various popular publications that the family and the nursery school were key sites for the incubation of democratic citizens. The wish to foster democratic values clearly appeared in her Nursery World columns. Child psychology had the potential to connect the intimate and the social. With her Kleinian ideas about unconscious aggression and anxieties in children, Isaacs noted the importance of the family in producing balanced and useful children, and she underscored the fragility of the family structure in achieving this aim. Failed parenting could result in delinquency or a revolt against the democratic order. ${ }^{103}$ It was therefore of national importance that parents and educators understood the emotions and desires of children. Using Isaacs' expert advice, parents could position themselves in a place of mutual respect and equality with their child, instead of maintaining a superior position as absolute rulers of the family. By looking more deeply at the motives behind children's rebellious or anti-social behaviour, and socially embarrassing bodily activities such as masturbation, one could tackle the 'repression' of sexuality or aggression. Parents' enhanced tolerance of their children, and the ability to pause, scrutinise and interpret their inner motives according to psychoanalytic principles, were needed, and Isaacs aimed to train her readers accordingly.

\footnotetext{
${ }^{100}$ Susan Isaacs, 'Is Your Child Excitable and Highly-Strung?' Nursery World, 7 October 1931, 640.

101 See Shapira, op. cit. (note 1); Harry Hendrick, Child Welfare: Historical Dimensions, Contemporary Debate (Bristol: The Policy Press, 2003).

102 Shapira, op. cit. (note 1), 17. Sally Alexander similarly argued that the ideas of Donald Winnicott, Isaacs' colleague, were part of the ethical and practical thinking that informed the British welfare state and the ethos of social democracy, see 'D.W. Winnicott and the social democratic vision', in Daniel Pick and Matt ffytche (eds), Psychoanalysis in the Age of Totalitarianism (London: Routledge, 2006),114-31.

103 Woolridge, op. cit. (note 6), 130.
} 
A child's naughty behaviour was now seen as a cry for help, breaking furniture a sign of deep anxiety, calling for apology rather than punishment. ${ }^{104}$ Understanding children meant educators must tolerate and contain aggressive and anti-social behaviour, scrutinising it for meaning. Nose-picking and phobias were imbued with coded meaning as Kleinian theory brought together day and night, waking life and dreams, play and the unconscious

Some letters written to Nursery World directly addressed the kind of cooperation and participatory agency required of democratic citizens. In a column from November 1929, a father asked Isaacs how to raise children not to 'shrink from responsibility', and become 'leaders rather than followers'. ${ }^{105}$ This concern was surely influenced by the rise of fascism in Europe. Isaacs explained that the 'nursery world is part of the larger world of social life', and has a role in preparing children for 'a social life based very largely upon the responsibility of the individual and upon mutual services'. ${ }^{106}$ Britons, she wrote, no longer inhabited a society 'where everything is built upon authority'. To reflect this change, she advised encouraging the development of social abilities in children while checking unwanted tendencies. This could be achieved by offering children as many choices as possible. Social responsibility and cooperation could be fostered through the companionship of other children. She wrote: 'The child's need for companionship is as great as his need for shelter and comfort. Without such real social experience he cannot grow into a responsible social being at any age. ${ }^{107}$ This envisioning of the ideal citizen suggests that democracy was understood at the time as peaceful, free of hierarchy and offering real choices to its citizens.

Obedience, Isaacs explained to her readers, was a method, not the final purpose of education. Parents or nurses aiming at absolute obedience from their children are likely to fall into a vicious cycle of scolding and defiance. Pausing and reflecting is advisable, and 'making a determined effort to get quite clear in our minds what it is all about...' One must remember that children live in the immediate present more than adults, and their desires are therefore more urgent. Respect from the child, she told caretakers, must be earned through giving respect to the child. Indeed, this was the opposite of the Victorian view of the child which required unquestioned obedience and checking their compulsive behaviour. Caregivers could now negotiate with the child, taking their wishes and desires into full consideration. The reasoning behind this approach was that 'the nursery needs to bear some relation to what will be asked of our children later in social life'. Isaacs argued that if democracy requires involvement and mutual respect among its citizens, raising children in blind obedience is counter-productive. ${ }^{108}$

A worried aunt whose nephew broke a precious watch and was scolded and smacked by his parents prompted Isaacs to extend the democratic right to property to children. If parents want children to respect their possessions they must respect theirs, she said. They should ask children, for example, if they may look at their book or move their building

\footnotetext{
${ }^{104}$ In the Malting School, a child spat in Isaacs' face, and she patiently asked him to apologise. See James Strachey's letter dated 17 February 1925 in Meisell and Kendrick (eds), op. cit. (note 34), 205.

105 Susan Isaacs, 'Leaders or Followers', Nursery World, 13 November 1929. Reprinted in Smith (ed.), op. cit. (note 6), 225.

106 Ibid., 225. Isaacs believed that the nursery school was an essential extension of the function of the family and the home. The school extended the range of the child's social contacts, creating a balance with the tight unit of the family as it allowed the child another outlet for feelings and emotions. See Susan Isaacs, Education Value of the Nursery School (London: Headly, 1952), 28-31.

107 Susan Isaacs, 'Leaders', op. cit. (note 105), 225.

108 Susan Isaacs, 'You Must Obey!', Nursery World, 20 November 1929. Reprinted in Smith (ed.), op. cit (note 6), 226-8.
} 
block off the table. ${ }^{109}$ In a democracy, children have rights, and respect for them will teach children respect for others, in turn. Isaacs linked adherence to property law to emotions and emotional relations; an education in emotional fairness in childhood would lead to a more stable democracy.

The parents and nurses writing to Isaacs often anxiously expressed a desire to 'make home life as happy as possible' for the child. They described their struggle to relinquish the disciplinary methods with which they themselves were raised, and adopt a modern, democratic approach. They were eager to be understanding, but still found themselves punishing or scolding their children, only to regret it later. In the Ursula Wise columns, letters adhere to a similar pattern: caregivers describe children's emotional difficulties, their defiant or anti-social behaviour, physical health, and sleeping, learning and eating habits. They then ask whether the child's problems require a psychologist's help in order that he or she will grow up to be a mature, democratic citizen. ${ }^{110}$

Mary, mother of a girl of six and a half, wrote of her daughter's difficulty sleeping and her nervous disposition, which led the mother to keep her home instead of sending her to school. Isaacs recommended gradually training the child to sleep on her own, and encouraging her independence. School, Isaacs believed, would enable independent play with other children, and would have a positive impact. ${ }^{111}$ These recommendations reflected the democratic requirement that citizens possess social skills and independent thought. ${ }^{112}$

As letter-writers sought advice in transitioning to 'modern' modes of parenting, Isaacs continued to emphasise the benefits of new psychoanalytic attitudes to the larger cause of fostering a healthy democracy. In a letter dated 15 January 1930, a 'student' asked Isaacs if she preferred the methods of 'old-fashioned' nurses to more modern ways. Challenging Isaacs, the student stated that children were happier with more traditional nurses. Isaacs responded by praising such nurses, whose best qualities were their clearly defined expectation of good behaviour, and expressing confidence that the child would meet their standards. However, such nurses could also be mean, even despotic. Isaacs wrote that few mothers and nurses were so clear-minded and were often unsure about the expectations they had of their child, especially as they 'began to ask more questions, and to inquire more deeply into the truth of child nature. . '. ${ }^{113}$ Older notions suggesting that 'children should be seen and not heard' had faded in popularity, but the spread of scientific knowledge was slow, leaving many confused. The remedy for this, Isaacs argued, was the serious study of child psychology. ${ }^{114}$

Between the wars, parents were particularly puzzled when their children were aggressive and destructive, though to Isaacs as a Kleinian, this was nothing new. The reader 'Worried', a mother of an unusually strong and destructive 3-year-old boy, described his terrible propensity for breaking things; he smashed windows and scratched

\footnotetext{
109 Susan Isaacs, 'The Punishment', Nursery World, 20 November 1929. Reprinted in Smith (ed.), op. cit. (note 6), 229.

${ }^{110}$ See for example, Susan Isaacs, 'Childhood Problems', Nursery World, 18 December 1929. Reprinted in Smith (ed.), op. cit. (note 6), 229-30.

111 See for example Susan Isaacs, 'Childhood Problems, Cont.', Nursery World, 25 December 1929. Reprinted in Smith (ed.), op. cit. (note 6), 231-2.

112 See also Susan Isaacs, 'The Value of Companionship', Nursery World, 26 March 1930. Reprinted in Smith (ed.), op. cit. (note 6), 238-9; see also Susan Isaacs, 'Training in Independence', Nursery World, 2 April 1930. Reprinted in Smith (ed.), op. cit. (note 6), 239-40.

113 Susan Isaacs, 'Old-Fashioned or Modern Methods', Nursery World, 15 January 1930. Reprinted in Smith (ed.), op. cit. (note 6), 235.

114 Ibid., 235-6.
} 
an expensive piano. This habit was costly, and no punishment seemed to help. Isaacs began with her usual sympathy, acknowledging that such a destructive child must cause the parents anxiety. Punishment is not the answer, she counselled, as it would have to be extraordinarily severe to check the boy's 'destructive impulse', thus permanently destroying his mental development. Instead she recommended active exercise, a good nursery and consulting a doctor to discover the cause of the difficulty. ${ }^{115}$ To other parents writing about their aggressive boys, Isaacs confirmed that outbursts of temper can be wearing on the nerves of mother or nurse (whom she still characterised as the only possible caregiver). These women worry too much, she wrote, and they fear the child is abnormal. Anxiety is heightened when child and caregivers share their fears with each other. In the spirit of the child guidance experts, Isaacs called upon her readers to examine themselves before examining their child's problems (a key modern idea which was emerging at the time, and which endures to this day). ${ }^{116}$

In a column provocatively titled 'Two Year Olds are often Cruel', Isaacs contended that cruelty to animals is common in children, as is the overall impulse to hurt. Advocating Klein's view that love and hate are intermingled, Isaacs added that one rarely sees a child who does not experience equally strong impulses for tenderness and sympathy with animals. Depending on their mood, children are either tender or hostile. As an educator, Isaacs recommended telling stories about animals to encourage compassion towards them. ${ }^{117}$

On 29 March 1933, a mother described her daughter's jealousy of her more beautiful sister. The previous help of a psychologist had seemed to resolve the problem, but it worsened again following the discriminatory intervention of an aunt. The mother asked Isaacs: 'do you think I could now discuss the matter openly with her, explain the misery that jealous nature is to anyone, tell her that she must try to control it?' The mother wondered whether she should send the girls to different schools. Isaacs, acknowledging 'the difficult situation', reminded her readers that jealousy is natural, and recommended sending the girls to different schools so that each child might have the chance to develop independently. ${ }^{118}$

Unkindness and greed between individuals posed a severe problem in the emotional economy of democracy. The reader 'Despairing', who confessed to reading the Ursula Wise columns every week with interest, was nurse to a boy with worrying traits: a tendency to be cruel to animals and other children, and terrible greed. When visiting others for tea, his manners were awful and he would take the nicest cakes for himself. Punishment and kind words had no effect. Isaacs noted that the lack of details about his early history made 'the origins of these two compulsions in the child' difficult to ascertain. She suggested that the nurse 'reflect' upon his history and try to 'discover' whether the child had been under strain earlier in life. Isaacs also wondered if charming manners were unreasonably emphasised in the education of children. Here she was able to teach her readers that 'compulsion' stems from a 'pressure for repression', writing: 'If we bottle him up too much in one direction he will burst out in another.' 119

\footnotetext{
115 Susan Isaacs, 'The Destructive Child', op. cit. (note 80), 73.

116 Susan Isaacs, 'The Mother's Attitude to the Child', Nursery World, 5 March 1930. Reprinted in Smith (ed.), op. cit. (note 6), 236-7.

${ }^{117}$ Susan Isaacs, 'Two Year Olds are often Cruel', Nursery World, 5 August 1931, 325.

118 Susan Isaacs, 'Jealousy', Nursery World, 29 March 1933, 325.

119 Susan Isaacs, 'Unkindness and Greed', Nursery World, 27 November 1935, 951.
} 
Isaacs was also concerned that aggression and corporal punishment would result in anti-social children. One nanny wrote to Isaacs to challenge and mock her, stating that she successfully stopped the little girl in her care from crying at night simply by smacking her. When the child day-dreamed instead of eating, the nurse smacked her again. Problems arose only when the child's mother treated her gently. The nurse complained: 'Where the upbringing of children is concerned, the present-day mothers are hopeless.' Uncharacteristically, Isaacs replied firmly that she would not allow anyone to use such methods with children. Smacking served the convenience of the nurse only. Caregivers should instead prioritise 'the health and happiness of the child at the present', thus ensuring 'satisfactory development, health, happiness, independence social responsibility, and full development of skills and interest in later childhood and in grown-up life'. Experience and research showed that the method used by the nurse could cause anti-social behaviour and severe neuroses. Moreover, it demonstrated a dangerous inability to understand the child's point of view, or to see the child as a person and a future adult citizen. ${ }^{120}$

\section{Conclusion}

Susan Isaacs' popular advice column quickly became a powerful medium for effectively training lay audiences in the core tenets of Kleinian psychoanalysis. Isaacs' work had diverse intellectual origins stemming from her academic and institutional career and the ideas of modern founders of childcare, such as Piaget and Burt. However, by the time she wrote for Nursery World she was a dedicated Kleinian and this, as shown, was clearly expressed in the magazine columns. Readers were encouraged to think about their children within a psychoanalytic framework, to consider their emotional history and to try to understand their internal anxieties. The fears of parents and caregivers were soothed, thanks to Isaacs' understanding approach. But even as she empowered the lay public to adopt and implement the analytic ideas of Klein, Isaacs contributed to maintaining the prestige and authority of specialists, directing readers to consult experts, read additional books and arrange for the professional treatment of their children. Isaacs' wide reach positioned her as a strong voice against behaviourist approaches to childcare. She did not hesitate to oppose behaviourism's emphasis on regularity and discipline above all else. Challenging the idea of enforcing habit on children, she thus reworked the moral imperative that dictated obedience rather than curiosity and participatory contribution. Thus, she played an important role in shifting popular childcare culture away from a parent-centric model of strict authority, which increasingly became associated with rising fascist regimes, and instead positioned childcare as a process for nurturing democratic subjects. Disciplinarian approaches did not disappear. But it now became common to approach children with understanding and empathy, and to acknowledge and reaffirm their subjective experiences, even when they presented conflict or aggression within their environment (as Isaacs saw reason and pattern in destructiveness). ${ }^{121}$

Isaacs' pragmatic rather than strictly theoretical approach no doubt contributed to her popularity. She rarely insisted on a single view. Instead, she gently pointed readers in the direction of analytic terminology and ways of thinking. This approach offered comfort to anxious parents and nurses, who were keen for her insights into the psychologically

${ }^{120}$ Susan Isaacs, 'I Smacked Her', Nursery World, 22 January 1936. Reprinted in Smith (ed.), op. cit. (note 8), 260-1. See also Susan Isaacs, 'A Child's Point of View', Nursery World, 4 June 1930. Reprinted in Smith (ed.), op. cit. (note 8), 245-55. This piece describes the changing power dynamic between nurses and children.

121 See also Urwin and Sharland, op. cit. (note 43), 183-5. 
complex view of the child. From the surviving records of her readers' responses, we see that they demonstrated an eagerness to receive her advice, even if they occasionally challenged her. The medium of the magazine's advice column restricted the length, thoroughness and theoretical scope of Isaacs' writing. Letter-writers tried to provide Isaacs with a detailed 'case history' of their troubled child, thus demonstrating the far-reaching influence of psychological attitudes. Despite the medium's limitations, Isaacs conveyed Klein's many complex psychoanalytic ideas with remarkable success. Her introduction to readers to consider their children's inner life proved increasingly popular in the inter-war period. Though her primary emphasis was on providing straightforward, practical advice, Isaacs, together with other psychoanalytic writers, infused her responses with newly developed theories and progressive conceptions of the child. ${ }^{122}$ Isaacs was an essential link between expert theories and popular child-rearing culture, shaping the education of a generation of children in the inter-war period.

\section{Acknowledgements}

I thank Jessica Levin, my beloved wife, for all her wisdom and her help. I am very grateful to Bonnie G. Smith, Susan Pedersen, the late John Forrester, the late Elizabeth Bott Spillius, Moshe Sluhovsky, Igal Halfin, Billie Melman, Eyal Shpringer, Keren Cohen, Roy Flechner, On Barak, Gil Rubin, Ronny Regev and Noam Maggor for their support. I would also like to thank the editors and the anonymous reviewers for their useful comments, and Lesley Marks for her editorial help. Some of the research for this article was generously supported by the Israel Science Foundation grant \#1417/14 and the Edmond J. Safra Center for Ethics at Tel Aviv University; it was partly conducted while on sabbatical at Barnard College, Columbia University (with Lisa Tiersten's very kind support).

122 Further studies on the process of popularisation of psychoanalysis by women analysts are called for, beyond the early work that was done in the field, see note 1 above. 